\title{
DEPOSITION RATE OF LAKE SEDIMENTS UNDER DIFFERENT ALTERNATIVE STABLE STATES
}

\author{
MICHAL GĄSIOROWSKI \\ Institute of Geological Sciences, Polish Academy of Sciences, \\ Twarda 51/55, 00-818 Warszawa, Poland
}

Received 3 June 2008

Accepted 21 August 2008

\begin{abstract}
Sediments of five shallow lakes in Polesie Lubelskie region (Eastern Poland), representing a wide range of nutrient concentration, were dated by $\mathrm{Pb}-210$ method and reliable age-depth models were constructed. These models were a base for studies of relationship between status of lake biocenoses and rate of sedimentation in the lakes.

The sedimentation rate does not depend on ecological status of studied lakes. The highest mean sedimentation rate was found in phytoplankton-dominated (Lake Syczyńskie) and phytoplanktonmacrophyte-dominated (Lake Sumin) lakes. Macrophyte-dominated lakes represented intermediate values of deposition rate. Lake depth, area and hydrology are more important factors controlling sedimentation rate. The sedimentation rate was rather stable or changed over the time, depending on human management in the lakes' drainage basins.
\end{abstract}

Keywords: ${ }^{210} \mathrm{~Pb}$ dating, sedimentation rate, alternative stable stages, shallow lakes, Polesie Lubelskie.

\section{INTRODUCTION}

The deposition rate of lake sediments is controlled by many factors. Lake morphology (area, depth, shoreline's length), water circulation, climate conditions, area and land use in the catchment, are only some of these features (Noges et al., 1999 and Ott et al., 2005). Some of them could be driven by human activity and thus rapid changes of sedimentation rate and historical events (e.g. settlement events, changes of predominant economy type, wars etc.) are often correlated. Sedimentation rate is also influenced by composition of plant and animal communities present in a lake.

According to the theory of alternative stable states, lakes can be classified as phytoplankton-dominated or macrophyte-dominated (Scheffer et al., 1993) with several intermediate steps (Moss, 1995). State of a lake is controlled by several factors, including nutrient concentration, turbidity, species composition of fish stock and catchment's characteristics. The state of a lake results in the character of prevailing material deposited on its bottom. Fragments of macrophytes, sometimes incrusted

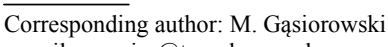

e-mail: mgasior@twarda.pan.pl

ISSN 1897-1695 (online), 1733-8387 (print) (C) 2008 GADAM Centre, Institute of Physics, Silesian University of Technology.

All rights reserved. with carbonates, are the main substrate of sediments in macrophyte-dominated lakes. Fine detritus is the major component of sediments in lakes dominated by phytoplankton. The dominant type of substrate does not determine a deposition rate of organic sediments and more important is the value of primary production in a lake. However, dense macrophyte cover may stabilize sediments, stop sediment transport and resuspension and thus impacts the rate of deposition in particular site of lake's floor.

This paper presents results of ${ }^{210} \mathrm{~Pb}$ measurements in sediments of five small and shallow lakes located in Eastern Poland. These lakes were previously studied in detail for hydrological and hydrobiological parameters (Kornijów et al., 2002a, b; Kornijów and Pęczuła, 2005; Smal et al., 2005). The lakes were selected since they represent different alternative states - from phytoplanktondominated (Lake Syczyńskie) through intermediate state (phytoplankton-macrophyte dominated Lake Sumin and Lake Głębokie) to dominated by submerged macrophytes (Lake Rotcze and Lake Kleszczów) (Kornijów et al., 2002a). Sediment dating and age-depth models were a base for studies of relationship between status of lake biocenoses and deposition rate of lake sediments. 


\section{STUDY SITES AND METHODS}

The studied lakes are located in Łęczna-Włodawa Lakeland (Fig. 1), a part of Polesie Lubelskie region (Eastern Poland). They are small (area up to $86 \mathrm{ha}$ ) and shallow lakes (Table 1). Sediment cores were collected from the central part of every lake using a gravitational Uwitec-corer. The collected cores were described and cut in the field into $1-\mathrm{cm}$ thin sections which were stored in plastic bags until analysis. In the laboratory, sediments were dried at $105^{\circ} \mathrm{C}$ overnight for water content determination and ashed in an oven at $550^{\circ} \mathrm{C}$ for loss-on-ignition (LOI).

For ${ }^{210} \mathrm{~Pb}$ analysis, a three cubic centimetre sample of homogenised sediment was taken from each level. The fresh sediment samples were weighed, dried, and weighed again to determine bulk density and water content. The ${ }^{210} \mathrm{~Pb}$ activity of sediments was determined indirectly by alpha-spectrometry measurement of ${ }^{210} \mathrm{Po}$ $\left(\mathrm{E}_{\alpha}=5.31 \mathrm{MeV}, \mathrm{T}_{1 / 2}=138\right.$ days) activity (Flynn, 1968) in the Laboratory of Institute of Geological Sciences of the Polish Academy of Sciences in Warsaw. ${ }^{210} \mathrm{Po}$ is generated by decay of ${ }^{210} \mathrm{~Pb}$ and then ${ }^{210} \mathrm{Bi}$ and is assumed to be in equilibrium with its parent isotopes. As an internal yield tracer, a known amount of ${ }^{208}$ Po was added to the weighed sample. Polonium was separated from the sample using concentrated hydrochloric and nitric acids and was deposited on silver disks (Flynn, 1968). The activity of ${ }^{210} \mathrm{Po}$ and ${ }^{208}$ Po was measured using an OCTETE PC alpha spectrometer produced by EG\&G ORTEC. A constant rate of unsupported ${ }^{210} \mathrm{~Pb}$ supply model (CRS) was used to calculate the sediment age (Appleby, 2001). This model assumes a variable sedimentation rate, sediment compaction and mixing. Activity of unsupported (allochthonous) ${ }^{210} \mathrm{~Pb}$ was calculated from total activity of ${ }^{210} \mathrm{~Pb}$ by subtraction of supported (authigenic) ${ }^{210} \mathrm{~Pb}$ activity.
Supported ${ }^{210} \mathrm{~Pb}$ was determined by measurements on old sediments (older than 150-200 years) which contain no allochthonous ${ }^{210} \mathrm{~Pb}$, assuming constant activity of authigenic ${ }^{210} \mathrm{~Pb}$ along the sediment column. An age-depth function was calculated using the randomisation method and was fitted using the LOESS procedure (Clevland and Devlin, 1988).

\section{RESULTS}

The collected sediments are silty gyttja, fine detritus gyttja and course detritus gyttja (Table 1). Organic matter content, expressed as LOI, was different in lakes (Fig. 2). LOI is relatively low in phytoplankton dominated (20-35\%) lake and significantly higher in macrophytedominated lake (up to $70 \%$ ). LOI changes also in specific

Table 1. Morphometric characteristic (after Smal et al., 2005) and sediment type of studied lakes.

\begin{tabular}{lccccc}
\hline & Kleszczów & Rotcze & Sumin & Głębokie & Syczyńskie \\
\hline $\begin{array}{l}\text { Maximal } \\
\text { depth }(\mathrm{m})\end{array}$ & 2.4 & 4.3 & 6.5 & 7.1 & 2.9 \\
\hline $\begin{array}{l}\text { Mean depth } \\
(\mathrm{m})\end{array}$ & 1.3 & 1.9 & 1.6 & 3.4 & 0.9 \\
\hline $\begin{array}{l}\text { Volume } \\
\left(\mathbf{1 0}^{3} \mathrm{~m}^{3}\right)\end{array}$ & 693 & 826 & 1454 & 689 & 51.19 \\
\hline $\begin{array}{l}\text { Lake } \\
\text { surface (ha) }\end{array}$ & 50.00 & 45.79 & 85.6 & 20.27 & 5.17 \\
\hline $\begin{array}{l}\text { Total catch- } \\
\text { ment area } \\
\text { (ha) }\end{array}$ & 253.38 & 157.19 & 1403.6 & 173.82 & 458.17 \\
$\begin{array}{l}\text { Sediment } \\
\text { type }\end{array}$ & $\begin{array}{c}\text { coarse } \\
\text { detritus } \\
\text { gyttja }\end{array}$ & $\begin{array}{c}\text { coarse } \\
\text { detritus } \\
\text { gyttja }\end{array}$ & $\begin{array}{c}\text { detritus } \\
\text { gyttja }\end{array}$ & $\begin{array}{c}\text { silty and } \\
\text { fine detri- } \\
\text { tus gyttja }\end{array}$ & fine detritus \\
$\begin{array}{l}\text { LOl } \\
\text { (\% of d.w.) }\end{array}$ & n.a. & $48-69$ & n.a. & 20-47 & $20-34$ \\
\hline
\end{tabular}

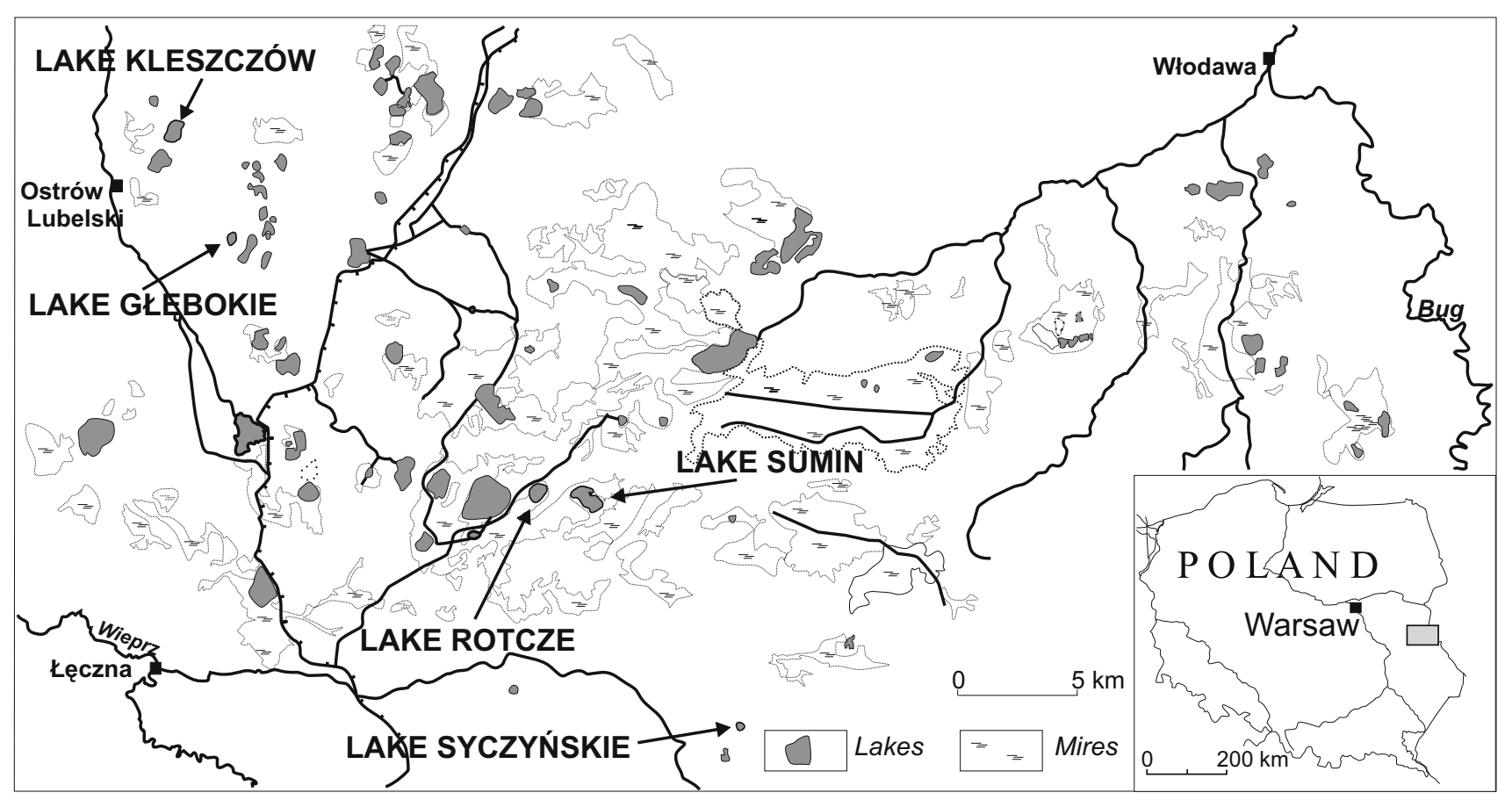

Fig. 1. Map showing a location of five shallow lakes. 

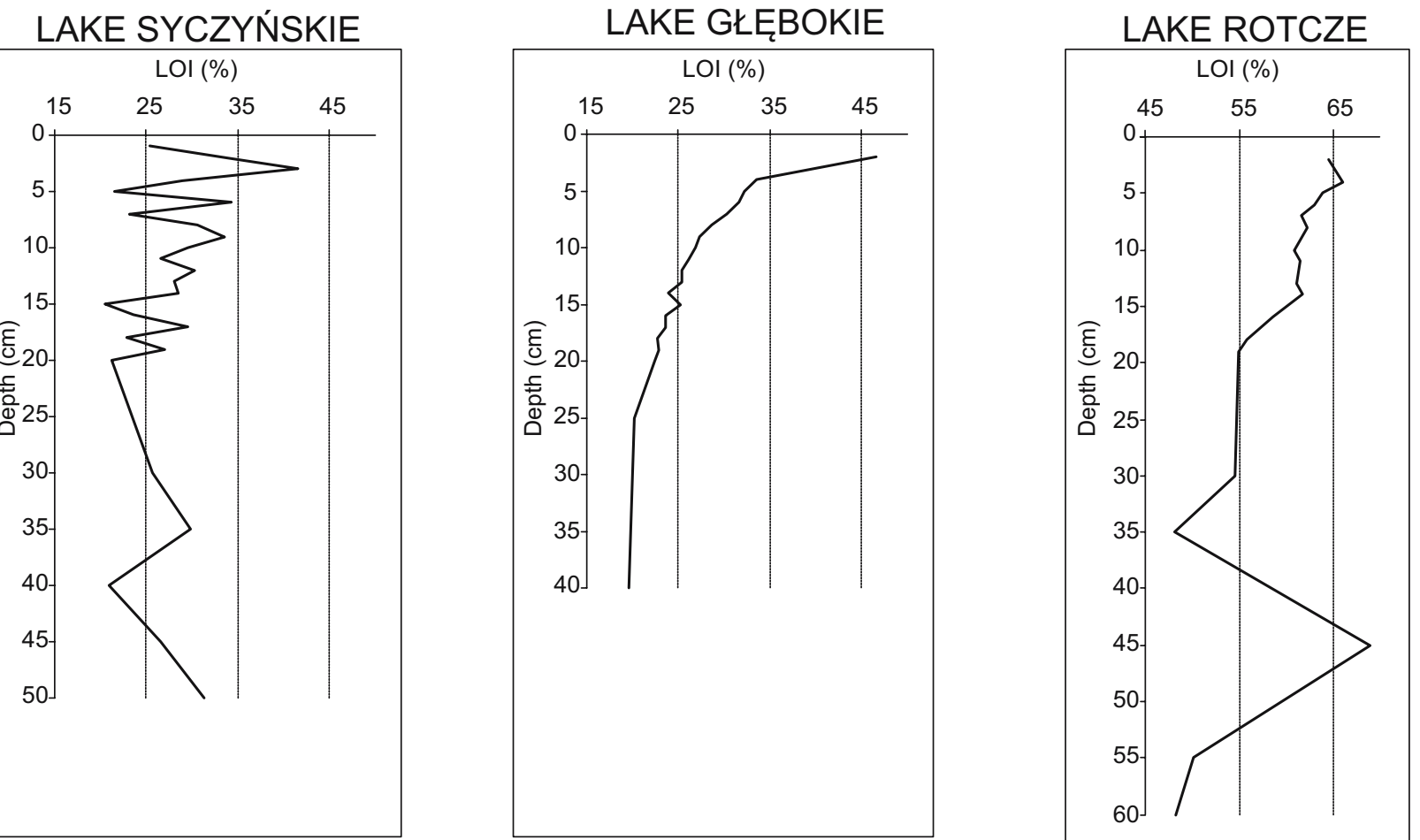

Fig. 2. Loss-on-ignition (LOI) in sediment of studied lakes. Data for Lake Kleszczów and Lake Sumin are not available.

lake along sediment column. In Lake Głębokie the LOI decreases with the depth from $47 \%$ in uppermost sample to circa $20 \%$ below $25 \mathrm{~cm}$, while in Lake Syczyńskie it oscillates between 20 and $40 \%$ in entire sequence.

Table 2 summarizes results of radiometric measurements. Total specific activity of ${ }^{210} \mathrm{~Pb}$ differs among studied sites and is the highest in Lake Rotcze and the lowest in Lake Syczyńskie. ${ }^{210} \mathrm{~Pb}$ concentration versus depth along the profile declines in a step-wise manner only in Lake Głębokie and Lake Syczyńskie (Fig. 3). In other cases, the several uppermost centimetres of sediment column (up to $15 \mathrm{~cm}$ in Lake Sumin) have uniform activities suggests some disturbances and/or sediment mixing. Activity of supported ${ }^{210} \mathrm{~Pb}$ was ca. $0.01 \mathrm{~Bq} \mathrm{~g}^{-1}$ in Lake Kleszczów, Lake Rotcze and Lake Syczyńskie. Lake Sumin and Lake Głębokie have considerably higher activities of supported ${ }^{210} \mathrm{~Pb}-0.025$ and $0.032 \mathrm{~Bq} \mathrm{~g}^{-1}$, respectively. The activity of unsupported ${ }^{210} \mathrm{~Pb}$ plotted on a logarithmic scale versus cumulative dry mass (Fig. 4) decrease almost linearly in Lake Głębokie and Lake Syczyńskie, but also in Lake Kleszczów and Lake Rotcze. Therefore, irregularities in activity profile in two latter lakes shown in Fig. 3 are related to density. Only for Lake Sumin the unsupported ${ }^{210} \mathrm{~Pb}$ profile is not well fitted and the estimated exponential equation explains $80 \%$ of variances suggesting changes of sedimetation rate.

Sediment age plotted versus sediment depth (Fig. 5) show different sedimentation rates. The lowest mean sedimentation rate was calculated for Lake Głębokie while the highest for Lake Sumin and Lake Syczyńskie (Table 2). Sedimentation rate in Lake Głębokie and Lake Sumin changed over the time and accelerated significantly after 1950 , from 1 and $1.3 \mathrm{~mm} \mathrm{yr}^{-1}$ up to 4 and
Table 2. Activity of ${ }^{210} \mathrm{~Pb}$ and sedimentation rate in five shallow lakes.

\begin{tabular}{|c|c|c|c|c|c|}
\hline & Kleszczów & Rotcze & Sumin & Głębokie & Syczyńskie \\
\hline $\begin{array}{l}\text { Maximal } \\
\text { activity of } \\
210 \mathrm{~Pb}\left(\mathrm{~Bq} \mathrm{~g}^{-1}\right)\end{array}$ & $\begin{array}{c}0.247 \\
\pm 0.011\end{array}$ & $\begin{array}{c}0.534 \\
\pm 0.014\end{array}$ & $\begin{array}{c}0.338 \\
\pm 0.012\end{array}$ & $\begin{array}{c}0.257 \\
\pm 0.015\end{array}$ & $\begin{array}{c}0.116 \\
\pm 0.004\end{array}$ \\
\hline $\begin{array}{l}\text { Activity of } \\
\text { supported } \\
\text { 210 } \mathrm{Pb}\left(\mathrm{Bq} \mathrm{g} \mathrm{g}^{-1}\right)\end{array}$ & $\begin{array}{c}0.010 \\
\pm 0.001\end{array}$ & $\begin{array}{c}0.01 \\
\pm 0.01\end{array}$ & $\begin{array}{c}0.025 \\
\pm 0.005\end{array}$ & $\begin{array}{c}0.032 \\
\pm 0.003\end{array}$ & $\begin{array}{c}0.012 \\
\pm 0.004\end{array}$ \\
\hline $\begin{array}{l}\text { Mean sedi- } \\
\text { mentation } \\
\text { rate during } \\
\text { the last } 150 \\
\text { yrs (mm } \mathrm{yr}^{-1} \text { ) }\end{array}$ & 2.7 & 3.0 & 3.3 & 2.3 & 3.4 \\
\hline $\begin{array}{l}\text { Mean sedi- } \\
\text { mentation } \\
\text { rate } \\
\left(\mathrm{g} \mathrm{cm}^{-2} \mathrm{yr}^{-1}\right)\end{array}$ & 0.035 & 0.019 & 0.064 & 0.049 & 0.055 \\
\hline
\end{tabular}

$6 \mathrm{~mm} \mathrm{yr}^{-1}$, respectively. In other lakes, the changes of sedimentation rate were minor.

\section{DISCUSSION}

Mean atmospheric fallout of ${ }^{210} \mathrm{~Pb}$ should be similar on regional scale (Appleby, 2001). Differences of unsupported ${ }^{210} \mathrm{~Pb}$ between lakes suggest that this assumption is not satisfied in the sites studied. However, dissimilarities in specific activity of ${ }^{210} \mathrm{~Pb}$ might reflect diverse sedimentation regime at coring sites and only imprecisely describe atmospheric fallout of lead to the lake. In Lake Rotcze, where the highest activity of unsupported ${ }^{210} \mathrm{~Pb}$ was measured, sediments consist mainly of plankton and detritus particles from in situ deposition. Hence, sediments transported from other parts of the lake do not 
SYCZ

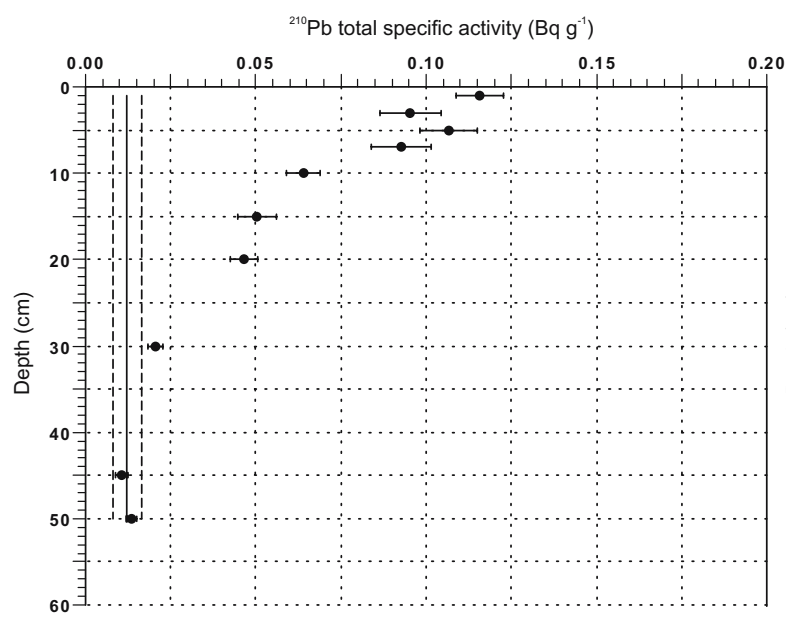

KLE

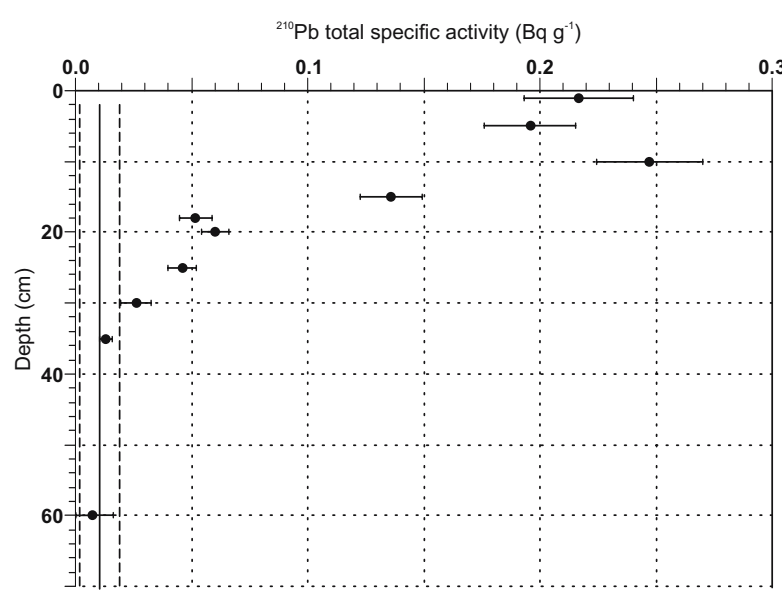

GUS

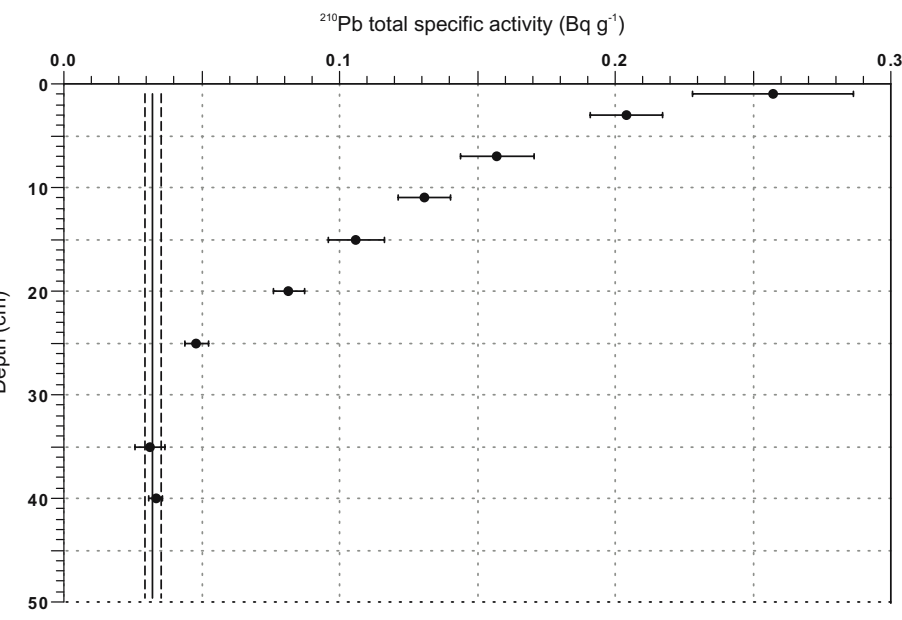

ROT

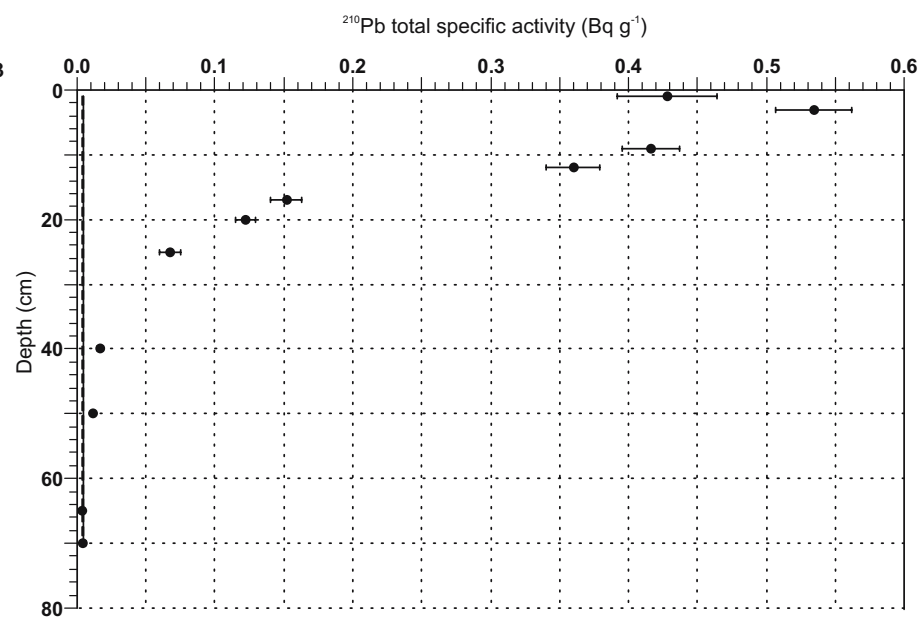

SUM

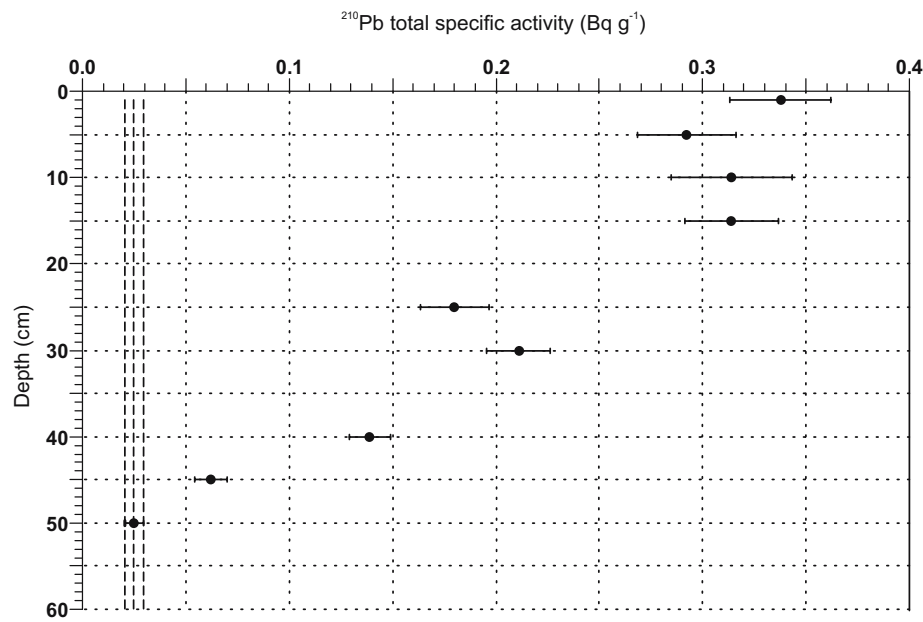

Fig. 3. Total activity of ${ }^{210} \mathrm{~Pb}$ versus sediment depth in studied lakes. The level of supported ${ }^{210} \mathrm{~Pb}$ (solid line) with $95 \%$ confidential range (dashed lines) was given. Abbreviations of lake names: SYCZ - Lake Syczyńskie, GUS - Lake Głębokie, KLE - Lake Kleszczów, ROT - Lake Rotcze, SUM - Lake Sumin. dilute falling ${ }^{210} \mathrm{~Pb}$. On the other hand, in Lake Syczyńskie, ${ }^{210} \mathrm{~Pb}$ input to the lake is dispersed by mineral matter transported from shore zone and by temporary inlets.

The profiles of total specific activity of ${ }^{210} \mathrm{~Pb}$ suggest that only sediments of lakes Głębokie and Syczyńskie are not mixed vertically. Both lakes are deep enough to ig- nore wind-induced water circulation and sediment mixing. Also benthos and fish activity responsible for bioturbation are strongly limited due to often oxygen deficits (Kornijów et al. 2002b; Kornijów and Halkiewicz 2007).

Unvarying activities of topmost part of sediment columns in lakes Sumin and Rotcze (Fig. 4) suggest sediment mixing or post-depositional migration of lead. The 
SYCZ

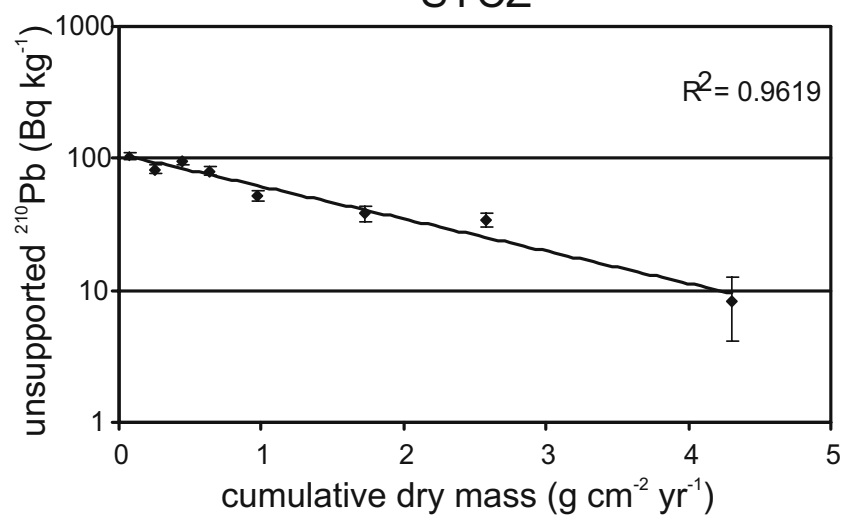

KLE

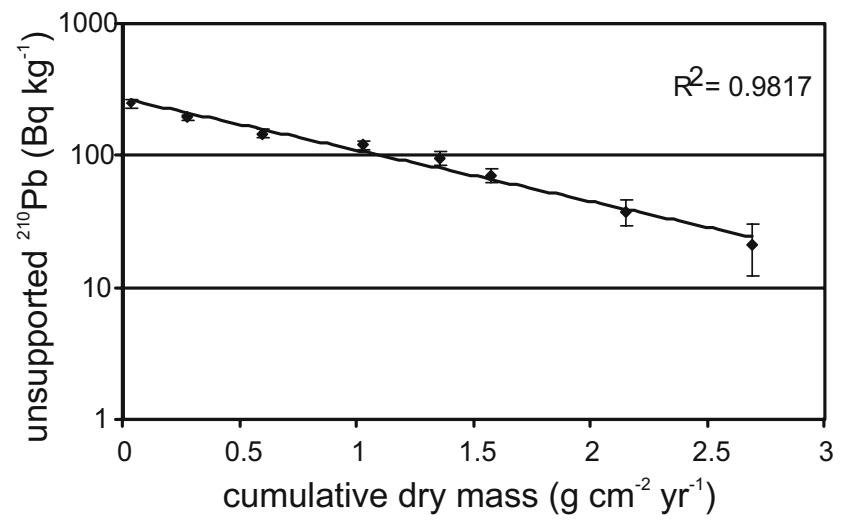

SUM

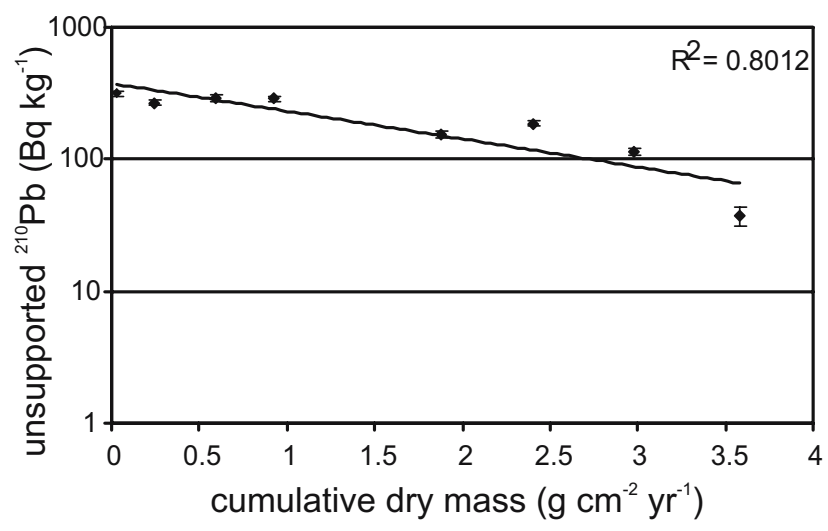

latter process can be excluded since it occurs in acidic conditions (e.g. Virkanen et al., 1997; Gaca et al., 2006). Coring process might cause surface-sediment mixing. Although, in all cases the same coring method was applied, the sediment type and water/sediment boundary character was different. Dense macrophytes covering lake floor in Lake Rotcze might complicate corer penetration into sediment and might be generating disturbance of sediment surface. On the other hand, macrophytes themselves could cause sediment mixing since they roots and rhizomes go through sediment. The deepest sediment mixing in Lake Sumin was probably due to latter factor and activity of benthic invertebrates.
GUS
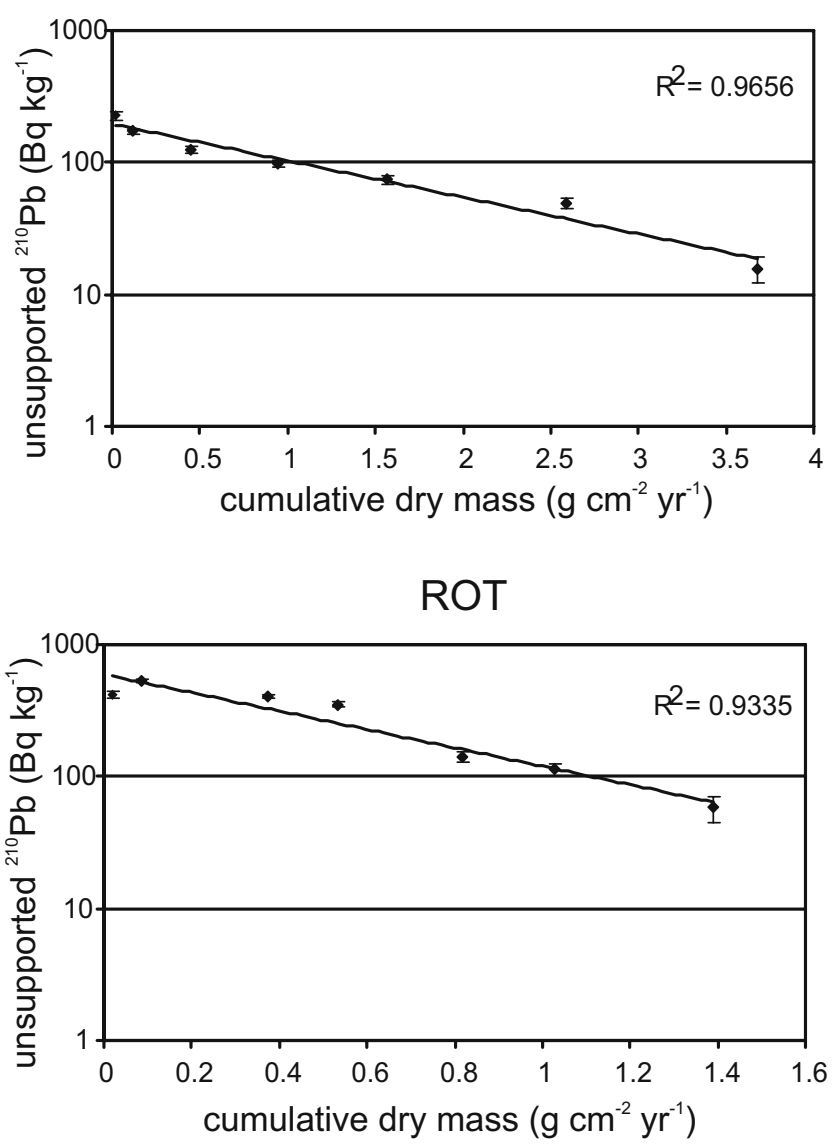

Fig. 4. Unsupported ${ }^{210} \mathrm{~Pb}$ plotted in logarithmic scale versus depth expressed as cumulative dry mass. Abbreviations of lake names are used as in Fig. 3.

The activity of supported ${ }^{210} \mathrm{~Pb}$ in Lake Kleszczów, Lake Rotcze and Lake Syczyńskie are similar to other lowland sites in Central Europe (Tylmann 2004, Gąsiorowski and Hercman 2005a, b). The activity of supported ${ }^{210} \mathrm{~Pb}$ in Lake Sumin and Lake Głębokie was significantly higher (Table 2), probably due to higher concentration of mineral matter in sediments.

Mean sedimentation rate varied from $2.3 \mathrm{~mm} \mathrm{yr}^{-1}$ in Lake Głębokie to $3.4 \mathrm{~mm} \mathrm{yr}^{-1}$ in Lake Syczyńskie. Lake Głębokie is the deepest among the studied lakes. Water circulation and offshore sediment transport is limited in the lake. This results in relatively low deposition rate in the central part, where the core was collected. On the contrary, Lake Syczynskie has the lowest area and mean 

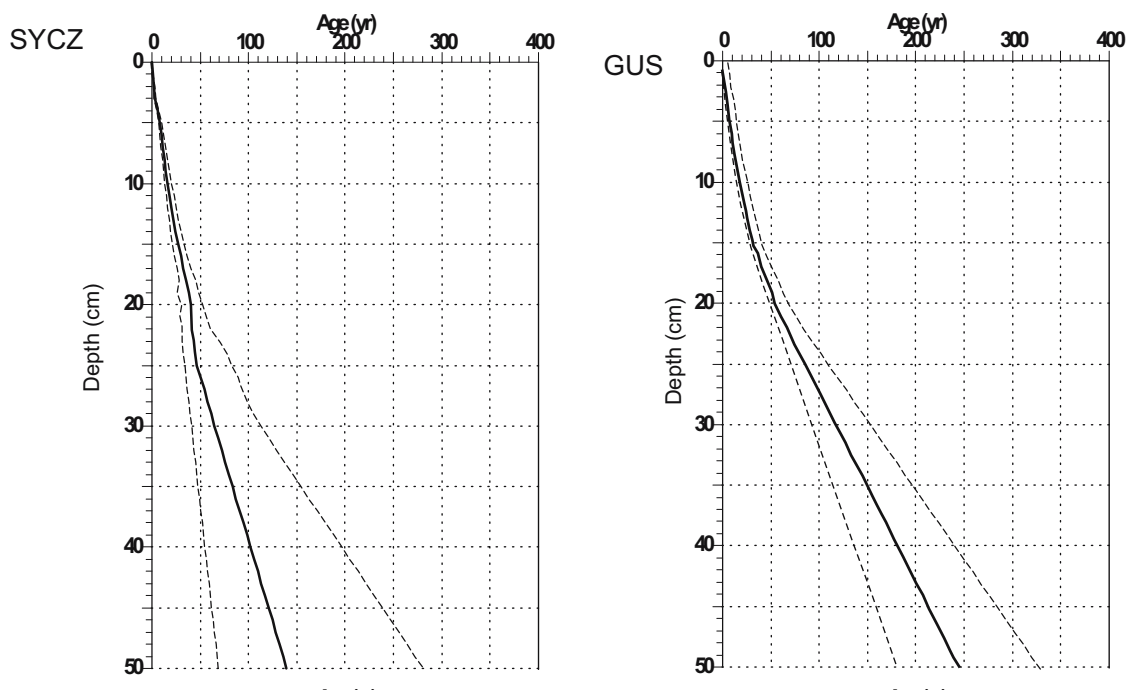

Fig. 5. Age-depth models (solid lines) based on ${ }^{210} \mathrm{~Pb}$ activities in sediments of five shallow lakes. Dashed lines are 95\% confidence bands. Abbreviations of lake names are used as in Fig. 3.
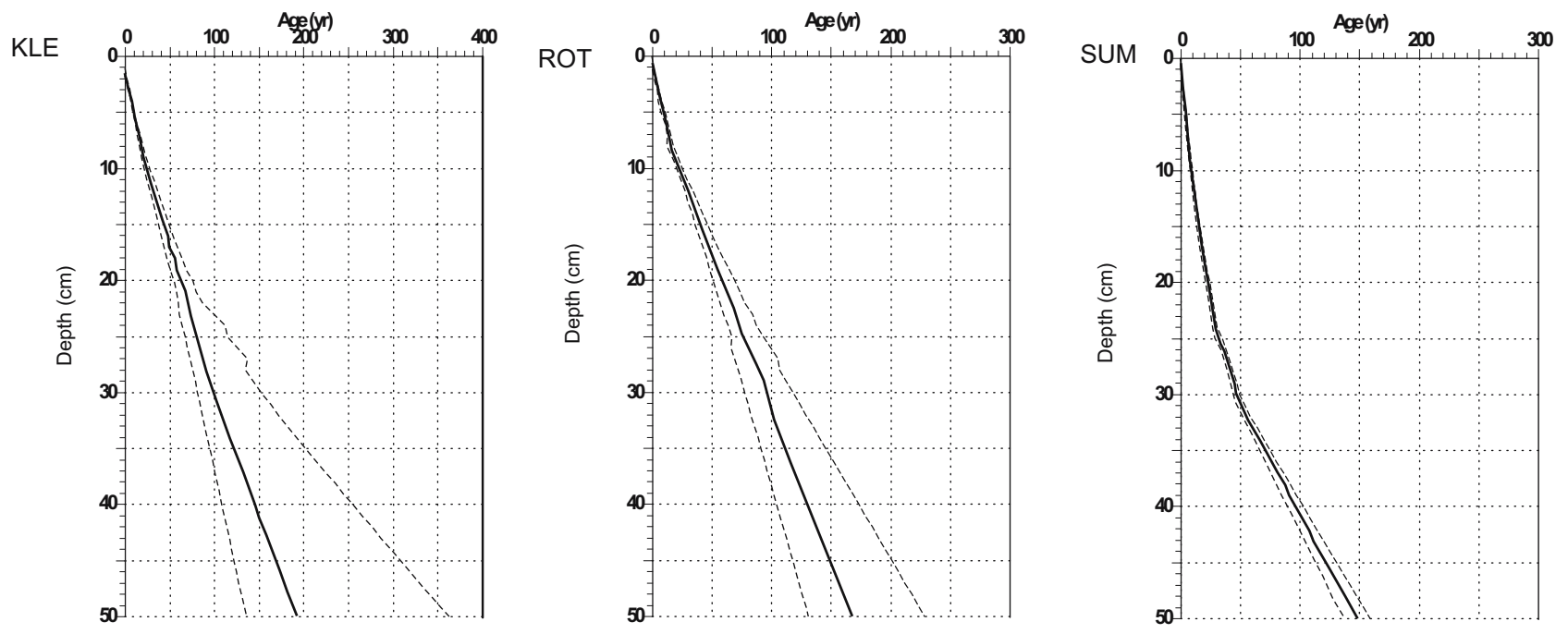

water depth among studied lakes. The sediment can be easily transported to the central part of the lake. Moreover, the temporary inlets transport allochtonous matter from the terrestrial catchment (Kornijów et al. 2002b). According to the theory of alternative stable states Lake Głębokie and Lake Syczyńskie were previously classified as phytoplankton-macrophyte-dominated and phytoplankton-dominated, respectively. Therefore, the mean sedimentation rate seems not to be strictly correlated with the state of the lake. The macrophyte-dominated Lake Kleszczów and Lake Rotcze have moderate mean sedimentation rate (Table 2). Hence, lake depth, area and hydrology control sedimentation rate while ecological state of lake is less important factor.

The sedimentation rates in the lakes: Rotcze, Kleszczów and Syczyńskie were rather stable during the last 150-200 years. However, the mechanism control the sedimentation rate stability is different in these lakes. Dense submerged macrophyte communities cover the lake's floor in the lakes Rotcze and Kleszczów and stabilise depositional condition. Conversely, sedimentation rates accelerated in Lake Głębokie and Lake Sumin after 1950 (Fig. 5) and were four times higher then before. The change might be correlated with changes of land use in the lakes' catchments (Chmielewski, 2003) and intensive melioration in 1950s (Chmielewski et al. 1997). The most important is the decrease of wetlands area surrounding the lakes. Marsh and meadow play a role of natural sediment trap and a buffer zone between lakes and arable fields. Arable land is a source of nutrients causing lakes eutrophication and biomass increase. The profile of LOI (Fig. 2) and the age-depth model (Fig. 5) indicate that anthropogenic eutrophication was a major factor increasing sedimentation rate in Lake Głębokie. Arable land constitutes significant part of Lake Głębokie and Sumin catchments ( 73.5 and $35.6 \%$, respectively), but more important is that the fields lie alongside the shores of the lakes (Smal et al., 2005). Among studied lakes also Lake Syczyńskie has high percentage of arable land in its catchment. However, the changes of land use structure during the last 50-60 years have not been so intensive there (Kornijów et al. 2002b). This results in a relatively high sedimentation rate during the whole studied period (the last 150 years).

\section{CONCLUSIONS}

1) Organic matter content, expressed as loss-on-ignition varies among shallow lakes and is the lowest in phytoplankton-dominated lake and the highest in macrophyte-dominated lake. 
2) Water depth, lake area, hydrology and nutrient load controlling sedimentation rate in studied shallow lakes while ecological state of studied lakes is a less important factor.

3) Anthropogenic changes, mainly changes in structure of land use in the lake's catchment could significantly increase sedimentation rate. The most sensitive to such changes are lakes without wetlands surrounding their shores.

4) Stratification in sediment sequences of phytoplankton-dominated lake and relatively deep phytoplankton-macrophyte dominated lake were not disturbed. In all other cases, the upper part of sediment column was a subject to intensive mixing, mainly due to macrophytes presence and activity of benthic invertebrates.

\section{ACKNOWLEDGMENT}

The author is grateful to Professor Ryszard Kornijów and anonymous reviewer for their helpful comments. This study was partly funded by Polish Committee for Scientific Research grant no 2 P06S00127.

\section{REFERENCES}

Appleby PG, 2001. Chronostratigraphic techniques in recent sediments. In: Last WM and Smol JP, eds, Tracking Environmental Changes Using Lake Sediments. Vol. 1: Basin Analysis, Coring, and Chronological Techniques. Dordrecht, Kluwer Academic Publishers: 171-203.

Chmielewski TJ, 2003. Changes of land-use boundaries over forty years (1952-92): The case of 11 catchment basins of lakes in the Polesie Lubelskie region (Eastern Poland). Polish Journal of Ecology 51: 117-128.

Chmielewski TJ, Radwan S and Sielewicz B, 1997. Changes in ecological relationships in a group of eight shallow lakes in the Polesie Lubelskie region (eastern Poland) over forty years. Hydrobiologia 342(0): 285-295, DOI 10.1023/A:1017064128937.

Cleveland WS and Devlin SJ, 1988. Locally-Weighted Regression: An approach to regression analysis by local fitting. Journal of the American Statistical Association 83: 596-610.

Flynn WW, 1968. The determination of low-levels of polonium-210 in environmental materials. Analytica Chemica Acta 43: 221-227, DOI 10.1016/S0003-2670(00)89210-7.
Gaca P, Tomankiewicz E, Mietelski JW, Grabowska S, Kubica B, 2006. Radionuclides in two rised peat profiles collected from Kościeliska Valley in the Tatra Mountains. Journal of Radioanalytical and Nuclear Chemistry 267(2): 443-448, DOI 10.1007/s10967-0060068-y.

Gąsiorowski M and Hercman H, 2005a. Recent changes of sedimentation rates in three Vistula oxbow lakes determined by ${ }^{210} \mathrm{~Pb}$ dating. Geochronometria 24: 33-39.

Gąsiorowski $M$ and Hercman H, 2005b. Recent sedimentation and eutrophication of Kruklin Lake after artificial drop in water-level in the middle of $19^{\text {th }}$ century. Studia Quaternaria 22: 17-25.

Kornijów R and Halkiewicz A, 2007. Uwarunkowania zaburzeń sekwencji odkładania osadów dennych w płytkich jeziorach poleskich w kontekście ich przydatności do badań paleoekologicznych. Studia Limnologica et Telmatologica 1: 83-86 (in Polish).

Kornijów R and Pęczuła W 2005. Ecosystem of a small and shallow lake suffering from cyanobacterial blooms - hypereutrophic, phytoplankton-dominated or both? Verhandlungen des Internationalen Verein Limnologie 29: 1015-1019.

Kornijów R, Pęczuła W, Lorens B, Ligęza S, Rechulicz J and Kowalczyk-Pecka D, 2002a. Shallow Polesie lakes from the view point of the alternative stable states theory. Acta Agrophysica 68: 61-72.

Kornijów R, Smal H, Pęczuła W, Lorens B, Rechulicz J, Sugier P, Paleolog-Demetraki A, Ligęza S, Tarkowska-Kukuryk M, Kowalczyk D, Szafran K and Halkiewicz A, 2002b. Hypertrophication of Lake Syczyńskie (Eastern Poland). Limnological Review 2: 209-215.

Moss B, 1995. The microwaterscape - a four-dimensional view of interaction among water chemistry, phytoplankton, periphyton, macrophytes, animals and ourselves. Water Sciences and Technology 32(4): 105-116, DOI 10.1016/0273-1223(95)00687-7.

Noges P, Tuvikene L, Noges T and Kisand A, 1999. Primary production, sedimentation and resuspension in large shallow Lake Vortsjarv. Aquatic Sciences 61(2): 168-182, DOI 10.1007/PL00001323.

Ott I, Rakko A, Sarik D, Noges P and Ott K, 2005. Sedimentation rate of seston during the formation of temperature stratification after ice break-up in the partly meromictic Lake Verevi. Hydrobiologia 547(1): 51-61, DOI 10.1007/s10750-005-4143-0.

Scheffer M, Hosper SH, Meijer ML, Moss B and Jeppesen E, 1993. Alternative equilibriums in shallow lakes. Trends in Ecology and Evolution 8(8): 275-279, DOI 10.1016/0169-5347(93)90254-M.

Smal H, Kornijów R and Ligęza S, 2005. The effect of catchment on water quality and eutrophication risk of five shallow lakes (Polesie region, Eastern Poland). Polish Journal of Ecology 53: 313-327.

Tylmann W, 2004. Estimating recent sedimentation rates using ${ }^{210} \mathrm{~Pb}$ on the example morphologically complex lake (Upper Lake Raduńskie, Poland). Geochronometria 23: 21-26.

Virkanen J, Korhola A, Tikkanen M, Blom T, 1997. Recent environmental changes in a naturally acidic rocky lake in southern Finland, as reflected in its sediment geochemistry and biostratigraphy. Journal of Paleolimnology 17(2): 191-213, DOI 10.1023/A:1007919922330. 